\title{
Single Strand Breaks Induced in DNA of Bacillus subtilis Cells by Mild Heating
}

Short Paper

In the course of investigation on the heat resistance of spores of Bacillus subtilis, we found that when the spores were heated at $90^{\circ} \mathrm{C}$ for $10 \mathrm{~min}$ in distilled water auxotrophic mutants were frequently produced (unpublished). This finding suggests that the DNA molecules in the spores are modified by heating.

Several papers have been published concerning the relationship between the sensitivity to mild $\left(50-52^{\circ} \mathrm{C}\right)$ heat or to ionizing radiation of several strains of Escherichia coli $i^{1-5)}$ and Salmonella typhimurium $^{6,7)}$ and the occurrence of single strand scissions in DNA molecules as a consequence of heating. It is expected that such single strand scissions of DNA molecules caused by heating can also be found in $B$. subtilis in certain circumstances.

In this paper, we show our study concerning the degradation of single strand DNA by mild heating in the vegetative cells of $B$. subtilis and its relation to the heat sensitivity of the cells.

Logarithmic-phase cultures of B. subtilis 168 (thy $\left.{ }^{-}, \mathrm{trp}^{-}\right)(168 \mathrm{Tt})$ were inoculated to $10 \mathrm{ml}$ of the modified Demain's medium ${ }^{8}$ supplemented with $20 \mu \mathrm{g} / \mathrm{ml}$ of tryptophan and $5 \mu \mathrm{Ci}$ of (methyl${ }^{14} \mathrm{C}$ ) thymine. The cultures were grown at $37^{\circ} \mathrm{C}$ to an optical density $(660 \mathrm{~nm})$ of 0.6 . The cells were then harvested, washed 3 times with $M / 15$ phosphate buffer (pH 7.2), and resuspended in the same buffer. The suspensions were incubated at $50^{\circ} \mathrm{C}$ for various periods.

The cells were converted to protoplasts by the treatment with $500 \mu \mathrm{g} / \mathrm{ml}$ of lysozyme in $7 \%$ sucrose-EDTA solution. After centrifugation, the protoplasts were suspended in distilled water. By this treatment the protoplasts were osmotically disrupted and DNA was released. The DNA was assayed for single strand breaks by zone sedimentation through alkaline sucrose density gradients. For sedimentation, a $4.6 \mathrm{ml}$ linear concentration gradient of $5-20 \%(\mathrm{w} / \mathrm{v})$ alkaline sucrose $(\mathrm{pH} 12)$ was used. A $0.1 \mathrm{ml}$ portion of $0.5 \mathrm{~N} \mathrm{NaOH}$ containing $2 \% \mathrm{SDS}$ and a $0.2 \mathrm{~m} l$ portion of ruptured vegetative protoplasts were layered on the top of the sucrose gradient by using a screw-pipette. The gradients were centrifuged at $30,000 \mathrm{rev} / \mathrm{min}$ for $90 \mathrm{~min}$ at $20^{\circ} \mathrm{C}$ in swinging-bucket rotors. After centrifugation, the contents were collected from bottom in fractions of $0.15 \mathrm{ml}$ on disks of filter paper. The disks were dried and counted in toluene system in scintillation counter.

Figure 1 shows the sedimentation profiles for single strand DNA isolated from $B$. subtilis $168 \mathrm{Tt}$ after 10,20 , and $30 \mathrm{~min}$ at $50^{\circ} \mathrm{C}$. After 10 and 20 min incubation at $50^{\circ} \mathrm{C}$ about 10 and $5 \%$, respectively, of the cells remained viable. The sedimentation distance of DNA was decreased in accordance with the decreasing of viability caused by heating.

Received January 5, 1977

枯草菌の細胞内 DNAの熱による単銷切断（内田 有恒・左子芳彦・門田 元: 京都大学農学部水産 学科水産微生物学研究室).

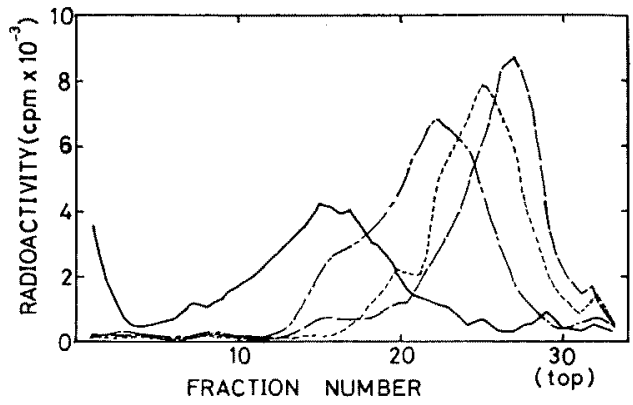

Fig. 1. Sedimentation patterns in alkaline sucrose density gradients of DNA from vegetative cells of $B$. subtilis; - - not heated; - ..., heated at $50^{\circ} \mathrm{C}$ for $10 \mathrm{~min}$ : -----, heated at $50^{\circ} \mathrm{C}$ for $20 \mathrm{~min}$; - heated at $50^{\circ} \mathrm{C}$ for $30 \mathrm{~min}$.

The single strand breaks of DNA as a consequence of heating at $50^{\circ} \mathrm{C}$ suggests that the polynucleotide strand may be degraded by nucleases. The radioactivity of the top of the gradient was very little. Thus, the single strand scissions may not be related to exonucleases. Our observations are not readily reconciled with the DNA strand degradation by the direct action, such as hydrolysis or depurination, of elevated temperature. As described by SEDGWICK and BRIDGES ${ }^{8)}$, these results are more consistent with attack by endonucleases released or activated by heating.

Aritsune UchIDA, Yoshihiko SAKo, and Hajime KaDotA

Laboratory of Microbiology, Department of Fisheries, Faculty of Agriculture, Kyoto University, Kyoto, Japan

\section{References}

1) B. A. Bridges, M. J. Ashwood-Smith, and R. J. Munson: J. gen. Microbiol., 58, 115124 (1969).

2) B. A. Bridges, M. J. Ashwood-Smith, and R. J. Munson: Biochem. Biophys. Res. Commun., 35, 193-196 (1969).

3) S. G. SedgWICK and B.A. BRidges: J. gen. Microbiol., 71, 191-193 (1972).

4) C. Pauling and L. A. Beck: J.gen. Microbiol., 87, 181-184 (1975).

5) C. Pauling, L. A. Beck, and S. P. WilczyNSKI: J. gen. Microbiol., 94, 297-304 (1976).

6) R. F. GOMEZ and A. J. SinSKEY: J. Bacteriol., 115, 522-528 (1972).

7) R. F. Gomez, K. D. Blais, A. Herrero, and A. J. SinskeY: J. gen. Microbiol., 97, 1927 (1976).

8) H. Kadota, K. Inima, and A. Uchida: Agr. Biol. Chem., 29, 870-875 (1965). 